\title{
INDUKSI PEMATANGAN GONAD IKAN GURAMI COKELAT (Sphaerichthys osphromenoides Canestrini, 1860) MENGGUNAKAN PREGNANT MARE SERUM GONADOTROPIN DAN ANTIDOPAMIN
}

\author{
Bastiar Nur, Sawung Cindelaras, dan Nina Meilisza
}

Balai Riset Budidaya Ikan Hias

(Naskah diterima: 22 November 2016; Revisi final: 6 April 2017; Disetujui publikasi: 6 April 2017)

\begin{abstract}
ABSTRAK
Ikan gurami cokelat (Sphaerichthys osphromenoides Canestrini, 1860) merupakan salah satu spesies ikan hias endemik perairan gambut dan memiliki potensi untuk dibudidayakan. Pada kondisi budidaya, berbagai faktor lingkungan yang berperan penting dalam menstimulasi perkembangan dan pematangan gonad hingga ovulasi dan pemijahan tidak mendukung aktivitas reproduksi beberapa spesies ikan. Penelitian ini dilakukan untuk menentukan dosis hormon yang efektif dapat merangsang pematangan gonad ikan gurami cokelat. Hormon yang digunakan adalah "Oodev®" (tersusun atas Pregnant M are Serum Gonadotropin/PMSG) dan antidopamin) yang diberikan menggunakan metode "topical gill". Ada tiga dosis 0odev ${ }^{\circledR}$ yang digunakan, yaitu: 0,02 mL; 0,04 mL; dan 0,06 mL; serta kontrol menggunakan $\mathrm{NaCl} 0,9 \%$ sebanyak $0,05 \mathrm{~mL} /$ $\mathrm{g}$ bobot badan ikan uji. Setiap perlakuan menggunakan 30 ekor induk betina ikan gurami cokelat (panjang total: $4,1 \pm 0,3 \mathrm{~cm}$; bobot: $1,41 \pm 0,17 \mathrm{~g}$ ). Pemberian hormon dilakukan setiap minggu hingga minggu ke7. Pada minggu ke-8 dilakukan pembedahan untuk pengambilan gonad. Parameter yang diamati adalah: jumlah induk matang gonad, indeks gonadosomatik (IGS), fekunditas, diameter oosit, kadar estradiol-17â dalam darah, dan tingkat kematangan gonad (TKG) ikan uji pada masing-masing perlakuan. Hasil penelitian menunjukkan bahwa perlakuan hormon dengan dosis $0,04 \mathrm{~mL} / \mathrm{g}$ bobot badan menghasilkan perkembangan gonad ikan uji yang lebih baik dengan jumlah induk matang gonad mencapai 23 ekor $(76,67 \%$, nilai IGS sebesar 2,33 $\pm 1,24 \%$ fekunditas sebesar 73,5 $\pm 26,2$ butir; diameter oosit berkisar antara 1,0-1,8 mm; kadar estradiol-17 $\beta$ dalam darah sebesar $15,9 \pm 4,5 \rho \mathrm{gg} / \mathrm{mL}$ dengan tingkat kematangan gonad mencapai tahap IV.
\end{abstract}

\section{KATA KUNCl: ikan gurami cokelat; pematangan gonad; hormon}

ABSTRACT: Induced maturation of chocolate gourami (Sphaerichthys osphromenoides Canestrini, 1860) using pregnant mare serum gonadotropin (PMSG) and antidopamin hormones. By: Bastiar Nur, Sawung Cindelaras, and Nina Meilisza

Chocolate gourami (Sphaerichthys osphromenoides Canestrini, 1860) is an endemic ornamental fish species in peatland waters and potentially to be cultivated. In captive condition, some environmental factors that play important role for gonadal development, maturation, ovulation, and spawning are not suitable for supporting reproductive activity in some fish species. This study was conducted to determine the optimum dosages of hormone which is able to stimulate gonadal maturation of chocolate gourami. Oodev ${ }^{\circledR}$ (consisted of Pregnant Mare Serum Gonadotropin (PMSG) and antidopamin) was given using "topical gill" method. There were three Oodev ${ }^{\circledR}$ dosages used in this research: $0.02 \mathrm{~mL} ; 0.04 \mathrm{~mL}$; and $0.06 \mathrm{~mL}$ respectively; and control using $0.05 \mathrm{~mL}$ of $0.9 \% \mathrm{NaCl}$ per gram of body weight. Each treatment was tested on 30 females (the averages of total length and body weight of $4.1 \pm 0.3 \mathrm{~cm}$ and $1.41 \pm 0.17 \mathrm{~g}$, respectively). Hormone was given every week until the seventh week. At the eight weeks, surgery was performed for gonadal measurement. Parameters measured were: number of gonadal maturebroodstocks, gonadosomatic index, fecundity, oocyte diameters, plasma estradiol-17â levels, and gonadal mature levels. The results showed that

\footnotetext{
\# Korespondensi: Balai Riset Budidaya Ikan Hias.

Jl. Perikanan No. 13, Pancoran Mas, Depok, Jawa Barat 16436, Indonesia.

Tel. + (021) 7520482

E-mail: bastiarnurdin@ gmail.com
} 
Induksi pematangan gonad ikan gurami cokelat (Sphaerichthys.... (Bastiar Nur)

$0.04 \mathrm{~mL}$ Oodev $\circledast$ per $\mathrm{g}$ body weight of fish was superior in reproductive performance. In that treatment, there were $76.67 \%(23 / 30)$ fish being matured, gonad somatic index $2.33 \pm 1.24 \%$ egg fecundity $73.5 \pm 26.2$ eggs, 0ocyte diameters ranged 1.0-1.8 mm, blood level of estradiol-17 $\beta 15.9 \pm 4.5 \rho \mathrm{g} \cdot \mathrm{mL}^{-1}$, and the level of gonad development reached to stage IV.

\section{KEYWORDS: chocolate gourami; gonadal maturation; hormone}

\section{PENDAHULUAN}

Perairan lahan gambut yang tersebar di Sumatera dan Kalimantan merupakan habitat yang banyak dihuni oleh ikan hias endemik. Salah satu spesies ikan hias yang mendiami habitat perairan gambut adalah ikan gurami cokelat (Sphaerichthys osphromenoides Canestrini, 1860). Ikan ini menjadi salah satu pilihan untuk mengisi akuarium ikan dan tanaman hias (aquascaping) yang diminati oleh masyarakat lokal dan mancanegara. Hingga saat ini kebutuhan ikan gurami cokelat masih mengandalkan hasil tangkapan alam dan belum berhasil dibudidayakan sehingga dapat berisiko terhadap kepunahannya. Di alam, status ikan ini mulai sulit ditemukan dan tidak cukup data untuk menilai risiko terhadap kepunahan sehingga dalam daftar International Union for Consevation of Nature berstatus belum dievaluasi (not evaluated) (IUCN 3.1). Namun ancaman kepunahan semakin terbuka lebar, mengingat lahan gambut sebagai habitatnya merupakan kawasan marginal yang banyak mengalami alih fungsi menjadi area pertambangan, lahan perkebunan, dan perumahan $(\mathrm{Ng} \&$ Kotellat, 1992). Oleh karena itu, budidaya ikan gurami cokelat perlu dilakukan untuk mengurangi ketergantungan dari alam demi menjaga kelestariannya.

Sifat endemisitas dan karakteristik lahan gambut yang unik menjadi salah satu faktor yang menyebabkan gangguan reproduksi ikan gurami cokelat yang dipelihara dalam lingkungan budidaya atau di luar habitat aslinya. Dalam lingkungan budidaya, beberapa ikan tidak dapat melangsungkan aktivitas reproduksinya yang disebabkan oleh hilangnya beberapa faktor lingkungan yang berperan dalam menstimulasi perkembangan dan pematangan gonad hingga ovulasi dan pemijahan (Keys \& Crocos, 2006; Mylonas et al., 2010; Lorenzen et al., 2012). Beberapa faktor lingkungan seperti suhu, fotoperiode, dan salinitas dapat dimanipulasi, namun membutuhkan biaya yang cukup mahal, terkadang tidak praktis, dan tidak efektif. Beberapa faktor lingkungan lainnya seperti migrasi pemijahan, kedalaman, dan tekanan air tidak mungkin disimulasikan untuk menstimulasi aktivitas reproduksi ikan (Gallego et al., 2012). Oleh karena itu, penggunaan hormon eksogen merupakan salah satu cara yang efektif untuk merangsang pematangan gonad maupun pemijahan pada ikan (Mylonas et al., 2010).
Salah satu hormon yang umum digunakan untuk mempercepat pematangan gonad pada beberapa jenis ikan adalah hormon Pregnant Mare Serum Gonadotropin (PMSG). Hormon PMSG memiliki sifat aktivitas biologis ganda sebagai hormon gonadotropin (GtH), yaitu berefek Follicle Stimulating Hormone (FSH) yang berperan pada proses perkembangan gonad (vitelogenesis) dan luteinizing hormone (LH) yang berperan pada proses pematangan akhir gonad (Nagahama \& Yamashita, 2008; Kumari et al., 2013). Laboratorium Reproduksi dan Genetika Ikan, Fakultas Perikanan dan IImu Kelautan, Institut Pertanian Bogor (IPB) telah mengembangan hormon PMSG dengan nama dagang "Oodev®". Hormon ini telah diuji pada beberapa jenis ikan untuk menginduksi pematangan gonadnya. Beberapa spesies ikan yang telah digunakan sebagai hewan uji hormon Oodev ${ }^{\circledR}$ oleh beberapa peneliti adalah ikan Tor soro (Wahyuningsih, 2012), belut sawah (Putra, 2013), ikan gabus (Hutagalung et al., 2015), dan beberapa jenis ikan lainnya dengan dosis efektif berdasarkan aturan pemakaiannya sebanyak 0,5 $\mathrm{mL} . \mathrm{kg}^{-1}$ bo bot badan ikan.

Pemilihan metode aplikasi hormonal didasarkan pada efektivitas, efisiensi, palatabilitas, kemungkinan polusi, dan biaya yang dibutuhkan (Emilda, 2012). Pada umumnya, aplikasi hormon pematangan gonad dilakukan melalui penyuntikan (injeksi), penanaman implan dalam jaringan tubuh (implantasi), dan melalui pakan (oral). Pemberian hormon Oodev ${ }^{\circledR}$ pada ikan uji secara umum diberikan melalui penyuntikan (injeksi) secara intramuskuler. Pada ikan yang berukuran kecil seperti pada ikan gurami cokelat, alternatif lain dalam pemberian hormon dapat dilakukan melalui mulut dengan insang sebagai organ targetnya. Metode ini dinamakan "topical gill", yaitu metode pemberian hormon yang diaplikasikan pada sebagian besar ikan-ikan yang berukuran kecil.

Aplikasi hormon Oodev $®$ belum pernah dilakukan terhadap ikan gurami cokelat, dan mengingat ukurannya yang kecil sehingga pemberian dengan metode "topical gill" menjadi pilihan yang diharapkan lebih efektif dalam mempercepat perkembangan gonadnya. Pada metode ini, hormon yang diberikan akan diserap oleh lamella insang (Hill et al., 2005). Menurut Sherwood \& Harvey (1986), terjadi penyerapan Gonadotropin-Releasing Hormoneyang bersumber dari mamalia ( $\mathrm{mGnRH}$ ) pada insang ikan maskoki (Carassius auratus) ketika 
air atau dimethyl sulfoxide (DMSO) digunakan sebagai pelarut mGnRH. Gonzalez-Martinez et al. (2006) menambahkan bahwa berdasarkan hasil analisis kualitatif dan kuantitatif menunjukkan adanya ekspresi reseptor GnRH tertentu dalam usus, insang, otot rangka, ovarium, lambung, dan limfa ikan Sparus aurata, dan level ekspresi reseptor GnRH dapat ditingkatkan secara signifikan dengan lokasi pengikatan tersebut. Keberadaan reseptor GnRH pada insang ikan diharapkan dapat mengikat hormon yang diberikan melalui tetes insang atau "topical gill" sehingga mampu memengaruhi perkembangan gonad ikan uji.

Oleh karena itu, penelitian ini dilakukan untuk menentukan dosis Oodev ${ }^{\circledR}$ yang tepat, serta menguji efektivitas 0 odev ${ }^{\circledR}$ dapat meningkatkan perkembangan gonad ikan gurami cokelat.

\section{BAHAN DAN METODE}

\section{Waktu dan Tempat Penelitian}

Penelitian ini dilakukan di Laboratorium Basah Bioreproduksi Balai Penelitian dan Pengembangan Budidaya Ikan Hias (BPPBIH) Depok pada bulan MeiAgustus 2015.

Sebanyak empat buah akuarium volume 150 liter $(100 \mathrm{~cm} \times 50 \mathrm{~cm} \times 40 \mathrm{~cm}$ ) sebagai wadah uji yang masing-masing dilengkapi dengan aerasi dan sistem air mengalir menggunakan top filter. Induk ikan gurami cokelat diperoleh dari nelayan pengumpul di Palembang, Sumatera Selatan; memiliki panjang total rata-rata 4,1 $\pm 0,3 \mathrm{~cm}$; serta rata-rata bobot badan $1,41 \pm 0,17$ g/ekor (Tabel 1). Padat tebar pada masingmasing wadah uji adalah sebanyak 30 ekor induk betina ikan gurami cokelat.
Sebelum diberi perlakuan hormon, ikan uji diadaptasikan terlebih dahulu selama satu bulan. Selama adaptasi, ikan uji dipelihara dalam bak beton volume 3.000 liter dengan sistem air mengalir dan dilengkapi dengan aerasi. Selama penelitian, ikan uji diberi pakan berupa cacing darah (bloodworm) secara satiasi (sekenyangnya) dengan frekuensi dua kali sehari.

\section{Aplikasi Hormon Oodev ${ }^{\circledR}$ dengan Metode "Topical Gill"}

Dosis Oodev ${ }^{\circledR}$ yang umumnya digunakan sebesar $0,5 \mathrm{~mL} / \mathrm{kg}$ atau $5 \times 10^{-4} \mathrm{~mL} / \mathrm{g}$ bobot badan ikan yang diberikan melalui penyuntikan secara intramuskuler. Pada penelitian ini, dosis Oodev ${ }^{\circledR}$ yang dicobakan adalah: 1) 0,02 mL; 2) 0,04 mL; 3) 0,06 mL/g bobot badan ikan; dan 4) kontrol menggunakan larutan fisiologis $\mathrm{NaCl} 0,9 \%$ sebanyak $0,05 \mathrm{~mL} / \mathrm{g}$ bobot badan ikan yang diberikan menggunakan metode "topical gill". Hormon diberikan dengan cara diteteskan menggunakan jarum suntik (syringe) kapasitas $1 \mathrm{~mL}$ melalui mulut agar hormon mencapai insang (metode "topical gill") sebagaimana yang dikemukakan oleh Hill et al. (2005). Sebelum pemberian hormon, ikan uji dianastesi menggunakan phenoxy ethanol sebanyak 0,3 $\mathrm{mL}$ per liter air. Ikan uji dibiarkan selama 3-4 menit setelah pemberian hormon sebelum dimasukkan ke wadah pemeliharaan agar hormon dapat diserap oleh reseptornya yang terletak di insang (Sherwood \& Harvey, 1986). Pada saat pemberian hormon, operkulum ikan uji ditutup agar hormon yang masuk ke insang tidak keluar melalui operkulumnya. Penelitian dilakukan selama delapan minggu. Pemberian hormon dan pengamatan perkembangan gonad dengan melihat morfologi perut ikan uji dilakukan setiap minggu hingga minggu ke-7. Pada

Tabel 1. Bobot ikan gurami cokelat sebelum perlakuan

Table 1. Weight of chocolate gourami broodstock before treatment

\begin{tabular}{lc}
\hline $\begin{array}{c}\text { Pelakuan dan dosis ( } \mathrm{mL} / \mathrm{g} \text { bobot badan) } \\
\text { Treatments and dosages (mL.g-1 body weight) }\end{array}$ & $\begin{array}{c}\text { Bobot } \\
\text { Weight }(\mathbf{g})\end{array}$ \\
\hline $\begin{array}{l}\text { Kontrol (Control) } \\
(\mathrm{NaCl}) 0.05\end{array}$ & $1.43 \pm 0.50$ \\
$\begin{array}{l}\text { Oodev }{ }^{8} \\
0.02\end{array}$ & $1.26 \pm 0.39$ \\
Oodev ${ }^{8}$ & \\
0.04 & $1.30 \pm 0.40$ \\
Oodev ${ }^{\circledR}$ & \\
0.06 & $1.63 \pm 0.44$ \\
\hline
\end{tabular}


minggu ke-8 dilakukan pembedahan untuk pengambilan gonad.

\section{Parameter Pengamatan dan Pengumpulan Data}

Parameter yang diamati pada penelitian ini adalah: persentase jumlah induk yang matang gonad, gonadosomatik indeks (GSI), tingkat kematangan gonad (TKG), fekunditas, diameter telur, dan kadar estradiol-17 $\beta$ dalam darah.

Induk yang matang gonad ditentukan berdasarkan penampilan perut yang membesar (morfologi) dan divalidasi melalui pembedahan pada akhir penelitian (minggu ke-8) untuk pengecekan gonad, serta histologi. Dari sejumlah induk yang matang gonad tersebut, enam ekor induk masing-masing yang memiliki penampilan perut paling besar dan paling kecil dipisahkan untuk dilakukan pembedahan. Sebelum dibedah, darah ikan diambil menggunakan jarum suntik (syringe) untuk pengukuran kadar estradiol-17 $\beta$ dengan metode ELISA menggunakan kit komersial (Catalog No. EIA 2693) yang diproduksi oleh Sigma. Gonad yang didapatkan kemudian ditimbang untuk menghitung nilai GSI. Sekitar 8-10 butir telur (oosit) dikeluarkan dari selaput pembungkus gonad untuk diamati diameternya menggunakan mikroskop dengan pembesaran 40 kali. Sampel gonad kemudian diawetkan menggunakan larutan Bouin untuk selanjutnya dilakukan pengamatan fekunditas dan histologi gonad menggunakan pewarnaan Hematoxylin-Eosin menggunakan metode Gunarso (1989). Penentuan TKG dilakukan berdasarkan hasil analisis histologi gonad yang mengacu pada Treasurer \& Holliday (1981) sebagaimana disajikan pada Tabel 2.

\section{Analisis Data}

Data ditabulasi menggunakan program Microsoft Excel dan disajikan secara deskriptif.

\section{HASIL DAN BAHASAN}

Hasil pengamatan parameter jumlah induk matang gonad, indeks gonadosomatik, fekunditas, diameter oosit, dan kadar estradiol-17 $\beta$ dalam darah disajikan pada Tabel 3. Hasil pengamatan tingkat kematangan gonad berdasarkan morfologi dan histologi gonad disajikan pada Tabel 4.

Secara umum, penggunaan Oodev ${ }^{\circledR}$ pada ikan gurami cokelat menunjukkan adanya peningkatan perkembangan gonad dibandingkan kontrol (Tabel 4). Perbedaan dosis hormon yang diberikan menghasilkan respons perkembangan gonad ikan uji yang berbeda. Penggunaan Oodev ${ }^{\circledR} \quad 0,04 \mathrm{~mL} / \mathrm{g}$ menghasilkan perkembangan gonad ikan uji yang lebih baik dengan nilai IGS yang dihasilkan sebesar $2,33 \pm 1,24 \%$ dan jumlah induk matang gonad sebanyak 23 ekor $(76,67 \%$. Hasil pengukuran oosit juga menunjukkan nilai yang lebih baik, ditunjukkan oleh jumlah telur (fekunditas) yang didapatkan sebesar 73,5 $\pm 26,2$ butir dengan diameter oosit paling besar yakni berkisar antara 1,0-1,8 mm (Tabel 3).

Ikan gurami cokelat yang tidak diberi perlakuan Oodev ${ }^{\circledR}$ (kontrol) menunjukkan tingkat kematangan gonad yang paling rendah dengan nilai IGS 1,57 \pm $0,96 \%$ dan jumlah induk yang matang gonad sebanyak enam ekor dari 30 ekor ikan uji $(20,00 \%)$. Data diameter oositnya tidak didapatkan karena oositnya masih menggumpal dan tidak dapat dikeluarkan dari selaput pembungkus gonad. Setelah perendaman gonad dalam larutan Boiun untuk pengamatan fekunditas dan analisis histologi, gumpalan oosit dalam gonad tidak dapat dipisahkan sehingga data fekunditas tidak diperoleh. Berdasarkan hasil analisis histologi, gonad ikan uji pada perlakuan kontrol ini masih berada pada TKG II (Tabel 4).

Penambahan Oodev ${ }^{\circledR}$ dengan dosis yang lebih tinggi $(0,06 \mathrm{~mL} / \mathrm{g}$ bobot badan) tidak menghasilkan peningkatan perkembangan gonad yang lebih baik. Hal ini diduga disebabkan karena terjadinya kelebihan konsentrasi FSH dalam tubuh sebagai akibat banyaknya dosis PMSG yang diberikan. Hafez et al. (2000) mengemukakan bahwa hormon PMSG merupakan korionik gonadotropin yang mempunyai sifat aktivitas biologis ganda, yaitu berefek FSH dan LH. Peningkatan FSH eksogen dapat menyebabkan terjadinya mekanisme umpan balik negatif oleh oosit sebelum oosit tersebut mencapai tingkat kematangan maksimal (TKG IV). Mekanisme ini menyebabkan penurunan aktivitas aromatase sehingga produksi estradiol-17 $\beta$ terhenti dan menyebabkan terhambatnya perkembangan oosit (Wahyuningsih, 2012). Hal ini diperkuat dengan hasil pengukuran kadar estradiol$17 \beta$ dalam darah di mana pada penggunaan 0 odev ${ }^{\circledR}$ $0,06 \mathrm{~mL} / \mathrm{g}$ memiliki kadar estradiol-17 $\beta$ lebih rendah $(16,0 \pm 4,1 \rho \mathrm{g} / \mathrm{mL})$ dibandingkan dengan perlakuan penggunaan $\operatorname{Oodev}{ }^{\circledR} 0,02 \mathrm{~mL} / \mathrm{g}(45,3 \pm 3,3 \rho \mathrm{g} / \mathrm{mL})$ dan pada saat yang sama tingkat kematangan gonad kedua perlakuan tersebut sama yaitu masing-masing berada pada TKG III (Tabel 4). Selain itu, kelebihan dosis hormon yang dimasukkan dalam tubuh ikan diduga tidak mampu diserap secara efektif oleh reseptor pada organ targetnya. Mylonas et al. (2010) berpendapat bahwa kelebihan dosis hormon yang dimasukkan ke dalam tubuh ikan dapat mengganggu keseimbangan jumlah hormon dalam tubuhnya, kelebihan hormon akan dikeluarkan oleh tubuh melalui sistem sekresi. 
Tabel 2. Ciri-ciri perkembangan gonad ikan berdasarkan histologi gonad

Table 2. Gonadal development characteristics based on histologycal gonad

\begin{tabular}{|c|c|c|}
\hline $\begin{array}{l}\text { Tingkat perkembangan } \\
\text { gonad } \\
\text { Level of gonadal } \\
\text { development }\end{array}$ & $\begin{array}{l}\text { Nama periode } \\
\text { Name of the period }\end{array}$ & $\begin{array}{l}\text { Deskripsi } \\
\text { Description }\end{array}$ \\
\hline 1 & $\begin{array}{l}\text { Oogonoia } \\
\text { Oogonium }\end{array}$ & $\begin{array}{l}\text { Dua ovarium primordial dipisahkan oleh lapisan epitel yang } \\
\text { mengandung sel primer, oogonia dan oosit primer } \\
\text { Two primordial ovaries separated by an epithelial layer containing primary } \\
\text { germ cells, oogonia and primary oocytes }\end{array}$ \\
\hline II & $\begin{array}{l}\text { Pra-vitelogenesis } \\
\text { Previtelogenesis }\end{array}$ & $\begin{array}{l}\text { Ovarium lebih berkembang: ovarium diselimuti lamella ovigerous } \\
\text { Ovarian more developed: ovarian covered lamella ovigerous } \\
\text { Ovary have increased: ovary was covered by lamella ovigerous }\end{array}$ \\
\hline III & $\begin{array}{c}\text { Perkembangan } \\
\text { awal } \\
\text { (vitelogenesis awal) } \\
\text { Early devel opment } \\
\text { (early vitelogenesis) }\end{array}$ & $\begin{array}{l}\text { Oosit semakin berkembang; folikel terdiri atas lapisan teka dan } \\
\text { granulosa; chorion yang terdiri tunica propria, zona radiata dan } \\
\text { jaringan terlihat longgar; terjadi pembentukan vesikel (granula) } \\
\text { kuning telur } \\
\text { Oocytes more developed; follicle comprises theca externa and granulosa; } \\
\text { chorion comprising tunica propria, zona radiata and a network looks } \\
\text { loose; formation of yolk vesicles }\end{array}$ \\
\hline IV & $\begin{array}{l}\text { Perkembangan } \\
\text { akhir } \\
\text { (vitelogenesis) } \\
\text { Late development } \\
\text { (vitelogenesis) }\end{array}$ & $\begin{array}{l}\text { Struktur oosit (bagian-bagian oosit) lebih jelas; ooplasma hampir } \\
\text { terisi penuh dengan granula kuning telur; chorion lebih luas } \\
\text { The structure of the oocyte (parts of the oocyte) more clearly; ooplasm } \\
\text { almost filled with yolk vesicles; chorion much wider }\end{array}$ \\
\hline
\end{tabular}

Sumber (Source): Treasurer \& Holliday (1981)

Tabel 3. Jumlah dan persentase induk matang gonad, kadar estradiol-17 $\beta$ dalam darah, indeks gonadosomatik, fekunditas, dan diameter oosit ikan gurami cokelat setelah perlakuan hormon

Table 3. Number and percentage of gonadal-mature broodstocks, plasma estradiol levels, gonadosomatic index, fecundity, and oocyte diameters of chocolate gourami after hormonal treatment

\begin{tabular}{|c|c|c|c|c|}
\hline \multirow{2}{*}{$\begin{array}{l}\text { Parameter } \\
\text { Parameters }\end{array}$} & \multicolumn{4}{|c|}{$\begin{array}{l}\text { Perlakuan dan dosis ( } \mathrm{mL} / \mathrm{g} \text { bobot badan) } \\
\text { Treatments and dosages ( } \mathrm{mL} . \mathrm{g}-1 \text { body weight) }\end{array}$} \\
\hline & $\begin{array}{l}\text { Kontrol (Control) } \\
\text { (NaCl) } 0.05\end{array}$ & $\begin{array}{c}\text { Oodev }{ }^{\circledR} \\
0.02\end{array}$ & $\begin{array}{c}\text { Oodev }{ }^{\circledR} \\
0.04\end{array}$ & $\begin{array}{c}\text { Oodev }{ }^{\circledR} \\
0.06\end{array}$ \\
\hline $\begin{array}{l}\text { Jumlah dan persentase } \\
\text { induk matang gonad (ekor dan \%) } \\
\text { Number and percentage of } \\
\text { gonadal-mature broodstocks (ind. and \%) }\end{array}$ & $6(20.00)$ & $17(56.67)$ & $23(76.67)$ & $20(66.67)$ \\
\hline $\begin{array}{l}\text { Indeks gonado somatik (\%); } n=6 \\
\text { Gonad somatic index (\%); } n=6\end{array}$ & $1.57 \pm 0.96$ & $2.18 \pm 1.73$ & $2.33 \pm 1.24$ & $2.29 \pm 1.12$ \\
\hline $\begin{array}{l}\text { Fekunditas (butir); } n=6 \\
\text { Fecundity (eggs); } n=6\end{array}$ & Th & $43.0 \pm 29.7$ & $73.5 \pm 26.2$ & $57.0 \pm 29.7$ \\
\hline $\begin{array}{l}\text { Diameter oosit } \\
\text { Oocyte diameters (mm) }\end{array}$ & Th & $0.6-1.1$ & $1.0-1.8$ & $0.5-1.3$ \\
\hline $\begin{array}{l}\text { Kadar estradiol-17 } \beta \text { darah }(\rho \mathrm{gg} / \mathrm{mL}) ; n=6 \\
\text { Plasma } 17 \beta \text {-estradiol levels }(\rho \mathrm{g} \cdot \mathrm{mL}-1) ; n=6\end{array}$ & $49.2 \pm 2.1$ & $45.3 \pm 3.3$ & $15.9 \pm 4.5$ & $16.0 \pm 4.1$ \\
\hline
\end{tabular}

Keterangan (Remark):th: tidak dapat dihitung, oositnya masih sangat kecil, menggumpal, dan sulit dipisahkan (th: not calculable, oocytes were very small, agglomerate, and difficult to separate) 
Tabel 4. Tingkat kematangan gonad berdasarkan struktur morfologi dan histologi gonad ikan gurami cokelat

Table 4. Gonad development stage based on structures of morphology and histology gonad of chocolate gourami

\begin{tabular}{lccc}
\hline $\begin{array}{c}\text { Pelakuan dan dosis } \\
\text { ( } \mathrm{mL} / \mathrm{g} \text { bobot badan) } \\
\text { Treatment and dosages } \\
\text { (ml.g-1 body weight) }\end{array}$ & $\begin{array}{c}\text { Morfologi gonad } \\
\text { Gonad morphology }\end{array}$ & $\begin{array}{c}\text { Histologi gonad } \\
\text { Gonad histology }\end{array}$ & $\begin{array}{c}\text { Tingkat kematangan } \\
\text { gonad } \\
\text { Gonad } \\
\text { development stage }\end{array}$ \\
\hline $\begin{array}{l}\text { Kontrol (Control) } \\
\text { (NaCl) } 0.05\end{array}$ & & II \\
\hline 0.05 & & \\
\hline \\
0.02
\end{tabular}

Konsentrasi estradiol-17 $\beta$ pada penggunaan hormon Oodev ${ }^{\circledR} 0,04 \mathrm{~mL} / \mathrm{g}$ bobot badan terlihat paling rendah. Hal ini diduga disebabkan estradiol$17 \beta$ telah dimanfaatkan dalam proses vitelogenesis sehingga pertumbuhan gonadnya menjadi lebih berkembang dan mencapai tahap TKG IV (Tabel 4). Hormon Oodev ${ }^{\circledR}$ yang mengandung PMSG yang diperoleh dari serum kuda hamil memiliki efek ganda sebagai FSH yang berperan pada proses vitelogenesis dan LH yang berperan pada proses pematangan akhir gonad (Gallego et al., 2012). Lebih lanjut lagi Hafez et al. (2000) menegaskan bahwa efek FSH dalam PMSG lebih dominan dibandingkan LH. FSH berperan dalam perkembangan oosit (vitelogenesis), sedangkan LH memicu kematangan oosit. FSH akan merangsang selsel teka melalui sistem CAMP untuk memproduksi testosteron. Selanjutnya testosteron dikonversi menjadi estradiol-17 $\beta$ oleh enzim aromatase sehingga menyebabkan terjadinya perkembangan oosit. Nagahama et al. (1995) menyatakan bahwa perkembangan oosit dari previtelogenesis ke vitelogenesis terjadi karena peningkatan produksi estradiol-17 $\beta$. Estradiol-17 $\beta$ kemudian masuk ke dalam sistem vaskuler dan merangsang hati untuk menyintesis vitelogenin (bakal kuning telur) dan menyekresikannya ke dalam peredaran darah menuju gonad sehingga terjadi pertumbuhan dan perkembangan oosit. 
Mekanisme hormonal pada perkembangan dan pematangan gonad ikan melibatkan $\mathrm{GnRH}$, gonadotropin, testosteron, enzim aromatase, estradiol$17 \beta$, dan neurotransmitter, serta dikontrol oleh sistem syaraf pusat (otak)-hypothalamus-pituitary-gonad (Nagahama, 1994; Yaron, 1995). FSH yang terkandung dalam PMSG bekerja pada lapisan teka oosit untuk merangsang terjadinya sintesis testosteron, yang selanjutnya masuk ke dalam lapisan granulosa oosit. Dalam lapisan granulosa, testosteron diubah oleh enzim aromatase menjadi estradiol-17 $\beta$ yang selanjutnya dibawa oleh aliran darah menuju hati dan merangsang hati untuk menyintesis vitelogenin (Nagahama, 1994; Yaron, 1995; Blazquet et al., 1998; Yaron \& Levavi-Sivan, 2011). Selain PMSG, hormon Oodev ${ }^{\circledR}$ juga mengandung antidopamin (AD) yaitu bahan kimia yang berfungsi memblok kerja dopamin; di mana dopamin merupakan neurotransmitter yang bekerja menghambat sekresi GnRH (FSHRH) dari hipotalamus (Cerda-Reverter \& Canosa, 2009; Kah, 2009; Van der Kraak, 2009), menghambat sekresi FSH dari pituitari dan dari sel gonadotropin melalui reseptor dopamin D2 (Vacher et al., 2000; Vacher et al., 2002), serta menghambat pematangan gonad melalui aksinya sebagai faktor penghambat pelepasan gonadotropin (Gonadotropin release-inhibiting faktor/ GRIF) (Dufour et al., 2005).

Keberhasilan induksi pematangan gonad menggunakan Oodev ${ }^{\circledR}$ dengan metode "topical gill" pada ikan gurami cokelat ini dapat dijadikan informasi dasar dalam upaya pematangan gonad ikan-ikan hasil domestikasi lainnya, terutama ikan berukuran kecil yang berisiko mengalami kematian apabila menggunakan metode penyuntikan (injeksi) dan penanaman implan dalam jaringan tubuh (implantasi). Namun upaya dalam memicu ovulasi dan pemijahan ikan gurami cokelat masih perlu dilakukan baik penentuan jenis hormon yang tepat maupun dosis yang efektif untuk menginduksi terjadinya pemijahan dalam lingkungan budidaya masih perlu dilakukan.

\section{KESIMPULAN}

Berdasarkan jumlah induk yang matang gonad, indeks gonadosomatik, fekunditas, serta diameter telur yang dihasilkan, penggunaan hormon Oodev ${ }^{\circledR}$ dengan dosis $0,04 \mathrm{~mL} / \mathrm{g}$ bobot badan ikan gurami cokelat yang diberikan setiap minggu selama delapan minggu efektif memacu perkembangan gonad ikan gurami cokelat.

\section{UCAPAN TERIMA KASIH}

Terima kasih kami ucapkan kepada Dr. Agus Oman Sudrajat, Departemen Budidaya Perairan, Fakultas Perikanan dan IImu Kelautan, Institut Pertanian Bogor
(FPIK-IPB) yang telah menyediakan hormon "Oodev ${ }^{\circledR}$ " yang digunakan pada penelitian, serta para teknisi Laboratorium Basah Bioreproduksi Balai Penelitian dan Pengembangan Budidaya Ikan Hias (BPPBIH) Depok (Acep Sutisna, S.Pd.; Dinar Tri Agustina, S.Pi.) yang telah membantu pelaksanaan penelitian ini. Penelitian ini merupakan kegiatan yang didanai oleh DIPA-APBN Tahun 2015.

\section{DAFTAR ACUAN}

Blazquet, M., Bosma, P.T., Fraser, E.J., Van Look, K.J.W., \& Trudeau, V.L. (1998). Review: Fish as models for the neuroendocrine regulation of reproduction and growth. Comparative Biochemistry and Physiology Part C, 119, 345-364.

Cerda-Reverter, J.M., \& Canosa, L.F. (2009). Neuroendocrine systems of the fish brain. In Bernier, N.J., Van der Kraak, G., Farrell, A.P., Brauner, C.J. (Eds.). Fish physiology volume 28. Academic Press. Burlington, p. 3-74.

Dufour, S., Weltzien, F.A., Sebert, M.E., Le Belle, N., Vidal, B., Vernier, P., \& Pasqualini, C. (2005). Dopaminergic inhibition of reproduction in teleost fishes, ecophysiological and evolutionary implications. Ann. N.Y. Acad. Sci., 1040, 9-21. DOI: 10.1196/annals.1327.002.

Emilda. (2012). Pemanfaatan ekstrak steroid asal jeroan teripang untuk sex reversal pada ikan gapi. Faktor Exacta, 5(4), 336-349.

Gallego, V., Mazzeo, I., Vílchez, M.C., Peñaranda, D.S., Carneiro, P.C.F., Pérez, L., \& Asturiano, J.F. (2012). Study of the effects of thermal regime and alternative hormonal treatments on the reproductive performance of European eel males (Anguilla anguilla) during induced sexual maturation. Aquaculture, (354), 7-16. DOI 10.1016/ j.aquaculture.2012.04.041.

Gonzales-Martínez, D., Sarasquete, C., Pascual, E., \& Muñoz-Cueto, J.A. (2006). Expression of gonadotrophin-releasing hormone binding sites in somatic tissues of the gilthead seabream (Sparus aurata): a quantitative autoradiographic study. Histol Histopathol, (21), 1065-1073.

Gunarso, W. (1989). Mikroteknik. Pusat Antar Universitas IImu Hayat. Institut Pertanian Bogor. Bogor, $117 \mathrm{hlm}$.

Hafez, E.S.E., Jainudeen, M.R., \& Rosnina, Y. (2000). Hormones, growth factors, and reproduction. In Hafez, B., \& Hafez, E.S.E. (Eds.) Reproduction in farm animals. USA: Lippincott Williams \& Wilkins, p. 33-54.

Hill, J.E., John, D.B., Jeffrey, S.G., Robert, L., James, F.F.P., \& Craig, A.W. (2005). Preliminary observations of topical gill application of reproductive 
hormones for induced spawning of a tropical ornamental fish. Technical Note. North American Journal of Aquaculture, 67, 7-9.

Hutagalung, R.A., Widodo, M.S., \& Faqih, A.R. (2015). Evaluasi aplikasi hormon PMSG (Oodev ${ }^{\circledR}$ ) terhadap indeks hepatosomatik dan gonadosomatik ikan gabus. Jurnal Akuakultur Indonesia, 14(1), 24-29.

Kah, O. (2009). Endocrine targets of the hypothalamus and pituitary. In Bernier, N.J., Van der Kraak, G., Farrell, A.P., \& Brauner, C.J. (Eds.). Fish physiology volume 28. Academic Press. Burlington, p. 75112.

Keys, S.J., \& Crocos, P.J. (2006). Domestication, growth and reproductive performance of wild, pond and tank-reared brown tiger shrimp (Penaeus esculentus). Aquaculture, 257, 232-240.

Kumari, N., Vashistha, N., Sharma, P., Godhwal, U., \& Muralidhar, K. (2013). Gonadotropin bioassays in the context of dual active pregnant mare serum gonadotropin (PMSG): A review. International Journal of Bioassays, 02(02), 370-375.

Lorenzen, K., Beveridge, M.C.M., \& Mangel, M. (2012). Cultured fish: integrative biology and management of domestication and interactions with wild fish. Cambridge Philosophical Society. Biological Reviews, 87(3), 639-660.

Mylonas, C.C., Fostier, A., \& Zanuy, S. (2010). Broodstock management and hormonal manipulations of fish reproduction. General and Comparative Endocrinology, 165, 516-534.

Nagahama, Y. (1994). Endocrine regulation of gametogenesis in fish. International Journal of Developmental Biology, 38, 217-229.

Nagahama, Y., Yoshikuni, M., Yamashita, M., Tokumoto, T., \& Katsu, Y. (1995). Regulation of oocyte growth and maturation in fish. Current Topics in Development Biology, 30, 103-145.

Nagahama, Y., \& Yamashita, M. (2008). Regulation of oocyte maturation in fish. Develop. Growth Differ., 50, S195-S219.

Ng, P.K.L., \& Kottelat, M. (1992). Betta livida, a new fighting fish (Teleostei: Belontiidae) from blackwater swamps in Peninsular Malaysia. Ichthyol. Explor. Freshw., (3), 177-182.
Putra, W.K.A. (2013). Induksi maturasi belut sawah (Monopterus albus) secara hormonal. Tesis. Sekolah Pascasarjana Institut Pertanian Bogor. Bogor, 54 hlm.

Sherwood, N.M., \& Harvey, B. (1986). Topical absorption of gonadotropin-releasing hormon (GnRH) in goldfish. General and Comparative Endrocrinology, 61, 13-19.

Treasurer, J.W., \& Holliday, F.G.T. (1981). Some aspects of the reproductive biology of perch (Perca fluviatilis $L$ ). A histological description of the reproductive cycle. Journal of Fish Biology, 18(3), 359376. DOI: 10.1111/j.1095-8649.1981.tb03778.x

Vacher, C., Mananos, E., Breton, B., Marmignon, M.H., $\&$ Saligaut, C. (2000). Modulation of pituitary dopamine D1 or D2 receptors and secretion of both FSH and LH during the annual reproductive cycle of female rainbow trout. Journal of Neuroendocrinology, 12(12), 1219-1226. DOI: 10.1046/ j.1365-2826.2000.00585.x

Vacher, C., Ferriere, F., Marmignon, M.H., Pellegrini, E., \& Saligaut, C. (2002). Dopamine D2 receptors and secretion of FSH and LH: role of sexual steroids on the pituitary of the female rainbow trout. General and Comparative Endocrinology, 127(2), 198206. DOI: $10.1016 / 50016-6480(02) 00046-1$.

Van der Kraak, G. (2009). The GnRH system and the neuroendocrine regulation of reproduction. In Bernier, N.J., Van der Kraak, G., Farrell, A.P., \& Brauner, C.J. (Eds.). Fish physiology volume 28. Academic Press. Burlington, p. 115-149.

Wahyuningsih, H. (2012). Induksi buatan pada perkembangan gonad ikan Tor soro. Disertasi. Sekolah Pascasarjana Institut Pertanian Bogor. Bogor, $94 \mathrm{hlm}$.

Yaron, Z. (1995). Endocrine control of gametogenesis and spawning induction in the carp. Aquaculture, 129, 49-73.

Yaron, Z., \& Levavi-Sivan, B. (2011). Endocrine regulation of fish reproduction. In Farrell, A.P. (Ed.). Encyclopedia of Fish Physiology: from genome to environment. San Diego: Academic Press, 2, 1500-1508. 